\title{
Growth of Cunninghamella elegans UCP 542 and production of chitin and chitosan using yam bean medium
}

\author{
Thayza Christina Montenegro Stamford \\ Núcleo de Pesquisa em Ciências Ambientais \\ Universidade Católica de Pernambuco \\ Rua Nunes Machado, 42 \\ Boa Vista. 50 050-590 Recife \\ PE, Brazil \\ Tânia Lucia Montenegro Stamford \\ Departamento de Nutrição \\ Universidade Federal de Pernambuco \\ Av. Professor Moraes Rego s/n \\ Cidade Universitária \\ 50 670-901 Recife \\ PE, Brazil \\ E-mail: leaal@nutricao.ufpe.br

\section{Newton Pereira Stamford} \\ Departamento de Agronomia \\ Universidade Federal Rural de Pernambuco \\ Rua Dom Manoel de Medeiros, $s / n$ \\ Dois Irmãos, 52171-900, Recife, PE, Brazil \\ E-mail: newtonps@fastmodem.com.br

\section{Benicio de Barros Neto} \\ Departamento de Química Fundamental \\ Universidade Federal de Pernambuco \\ Av. Professor Moraes Rego s/n \\ Cidade Universitária, 50 670-901 Recife, PE, Brazil \\ E-mail:bbn@ufpe.br \\ Galba Maria de Campos-Takaki \\ Departamento de Química \\ Núcleo de Pesquisa em Ciências Ambientais \\ Universidade Católica de Pernambuco \\ Rua Nunes Machado, 42 \\ Boa Vista. 50 050-590 Recife \\ PE, Brazil \\ Tel: 558132164017 \\ Fax: 558132164043. \\ E-mail: takaki@unicap.br \\ Website: http://www.unicap.br
}

Financial support: Conselho Nacional de Desenvolvimento Científico e Tecnológico (CNPq), Coordenação de Aperfeiçoamento de Pessoal de Nível Superior (CAPES), and the Universidade Católica de Pernambuco (UNICAP).

Keywords: biopolymers, chitin, chitosan, Cunninghamella elegans, Zygomycetes.

Abbreviations: $\quad$ DD: Deacetylation degree

PDA: Potato Dextrose Agar

Microbiological processes were used for chitin and assay was carried out to evaluate the growth of $C$. chitosan productions by Cunninghamella elegans (UCP elegans using yam bean (Pachyrhizus erosus L. Urban) 542) grown in a new economic culture medium. The medium, in different times of growth $(24,48,72$ and 96

*Corresponding author 
hrs), incubated at $28^{\circ} \mathrm{C}$ in an orbital shaker at $150 \mathrm{rpm}$. The lyophilized biomass was determined by gravimetry. The polysaccharides were extracted by alkali-acid treatment, and characterized by infrared spectroscopy, titration and viscosity. C. elegans grown in the yam bean medium and produced higher yields of biomass $(24.3 \mathrm{~g} / \mathrm{mL})$ in $96 \mathrm{hrs}$. The high level was chitosan (66 $\mathrm{mg} / \mathrm{g}$ ), and chitin $(440 \mathrm{mg} / \mathrm{g})$ were produced at 48 and 72 hrs of growth, respectively. The polysaccharides showed degree of deacetilation and viscosimetric molecular weight as: $6.2 \%$ and $3.25 \times 10^{4} \mathrm{~g} / \mathrm{mol}$ for chitin, and $85 \%$ and $2.72 \times 10^{4} \mathrm{~g} / \mathrm{mol}$ for chitosan, respectively. The results obtained suggest high biotechnological potential of yam bean as an economic source to produce chitin and chitosan by $C$. elegans. In addition, the new medium using yam bean for production of the chitin and chitosan may be used for many purposes to reduce the cost price of fermentation processes.

Chitin, the insoluble linear $\beta 1,4-$ linked homopolymer of Nacetyl-D-glucosamine (GlcNAc), is the second most abundant natural polysaccharide (after cellulose). Chitosan is a cationic amino polysaccharide, essentially composed of $\beta-1,4$ D-glucosamine (GlcNAc) linked to N-acetyl-Dglucosamine residues (Andrade et al. 2000; CamposTakaki, 2005), derived from de-N-acetylation of chitin (Tharanathan and Kittur, 2003; Amorim et al. 2005). These polysaccharides are found in a wide range of natural sources, such as crustaceans, insects annelids, molluscs, coelenterates and is a common constituent of fungal cell walls (Andrade et al. 2003; Synowiecki and Al-Khatteb, 2003; Franco et al. 2005).

Chitin and chitosan hold a great economic value as due to their versatile biological activities and chemical applications, mainly in medical (Murugan and Ramakrishna, 2004; Yadav and Bhise, 2004) and pharmaceutical (Takeuchi et al. 2001; Kato et al. 2003) areas. The wide range of applications of these polymers has been extensively studied (Dos Santos et al. 2003; Yusof et al. 2003; Campos-Takaki, 2005). Chitin and chitosan show peculiar properties, such as: biodegradability, biocompatibility, bioactivity, selective permeability, polieletrolic action, chelation, ion exchange properties, antitumor and antimicrobial activity (Dos Santos et al. 2003; Chung et al. 2004; Yadav and Bhise, 2004), and adsorption capacity (Shigemasa and Minami, 1996; Tharanathan and Kittur, 2003; Franco et al. 2004).

Recent advances in fermentation technologies suggest that the cultivation of selected fungi can provide an alternative source of chitin and chitosan. The amount of these polysaccharides depends of the fungi species and culture conditions (Tan et al. 1996; Pochanavanich and Suntornsuk, 2002; Andrade et al. 2003; Synowiecki and AlKhatteb, 2003). Filamentous fungi have been considered an attractive source of chitin and chitosan for industrial applications because their specific products can be manufactured under standardized conditions (Synowiecki and Al-Khatteb, 1997; Pochanavanich and Suntornsuk, 2002; Nemtsev et al. 2004). Usually, the Zygomycetes Class has higher amounts of chitin and chitosan in their cell walls when compared to other classes of fungi (Andrade et al. 2000; Campos-Takaki, 2005; Franco et al. 2005).

The use of biomass from fungi has demonstrated great advantages, such as: independence of seasonal factor, wide scale production, simultaneous extraction of chitin and chitosan, extraction process is simple and cheap resulting in reduction in time and cost required for production, and also absence of proteins contamination, mainly the proteins that could cause allergy reactions in individuals with shellfish allergies (Andrade et al. 2000; Amorim et al. 2001; Nadarajah et al. 2001; Andrade et al. 2003; Franco et al. 2005). However, to optimize the production of chitin and chitosan from fungi, it's usually used complex or synthetics cultures media, which are expensive. It's becomes necessary to obtain economic culture media that promote the growth of fungi and stimulate the production of the polymers.

Ecomonic microbial culture media normally use vegetables components. Yam bean (Pachyrhizus erosus L. Urban) is a leguminous plant native from the Amazon region and from Mexico semiarid region (Sorensen, 1996). The leguminous produces comestible tubercles and seeds with high level of protein and lipids. The tubercles were used as a good starch source for several industrial purposes (Sarangbin and Watanapokasin, 1999; Stamford et al. 1998; Stamford et al. 2001). The main characteristic of yam bean is the simple manipulation and low nutrition requirements when compared with other similar cultures, and tuberous roots yields is up to $60 \mathrm{t} / \mathrm{ha}$ (Stamford et al. 1998; Stamford et al. 2001; Stamford et al. 2003).

The present paper aims to investigate the chitin and chitosan production using the Mucoralen fungi Cunninghamella elegans (UCP 542), grown by submerse fermentation in economic culture medium, yam bean (Pachyrhizus erosus L. Urban), as substrate, and was compared with four traditional culture media.

\section{MATERIALS AND METHODS}

\section{Microorganisms}

Cunninghamella elegans UCP 542 (Culture Collection of Catholic University of Pernambuco, Recife, Brazil) isolated from mangrove sediment situated in Rio Formoso, PE, Brazil. The strain was maintained at $4^{\circ} \mathrm{C}$ on Potato Dextrose Agar (PDA) slants.

\section{Culture medium}

C. elegans was grown, for chitin and chitosan production, in five different culture media: a) Sabouraud sucrose(bacteriological peptone $(10 \mathrm{~g})$ and sucrose $(20 \mathrm{~g})$ per litre of distilled water, $\mathrm{pH} 5.7)$; b) Hesseltine and Anderson- 

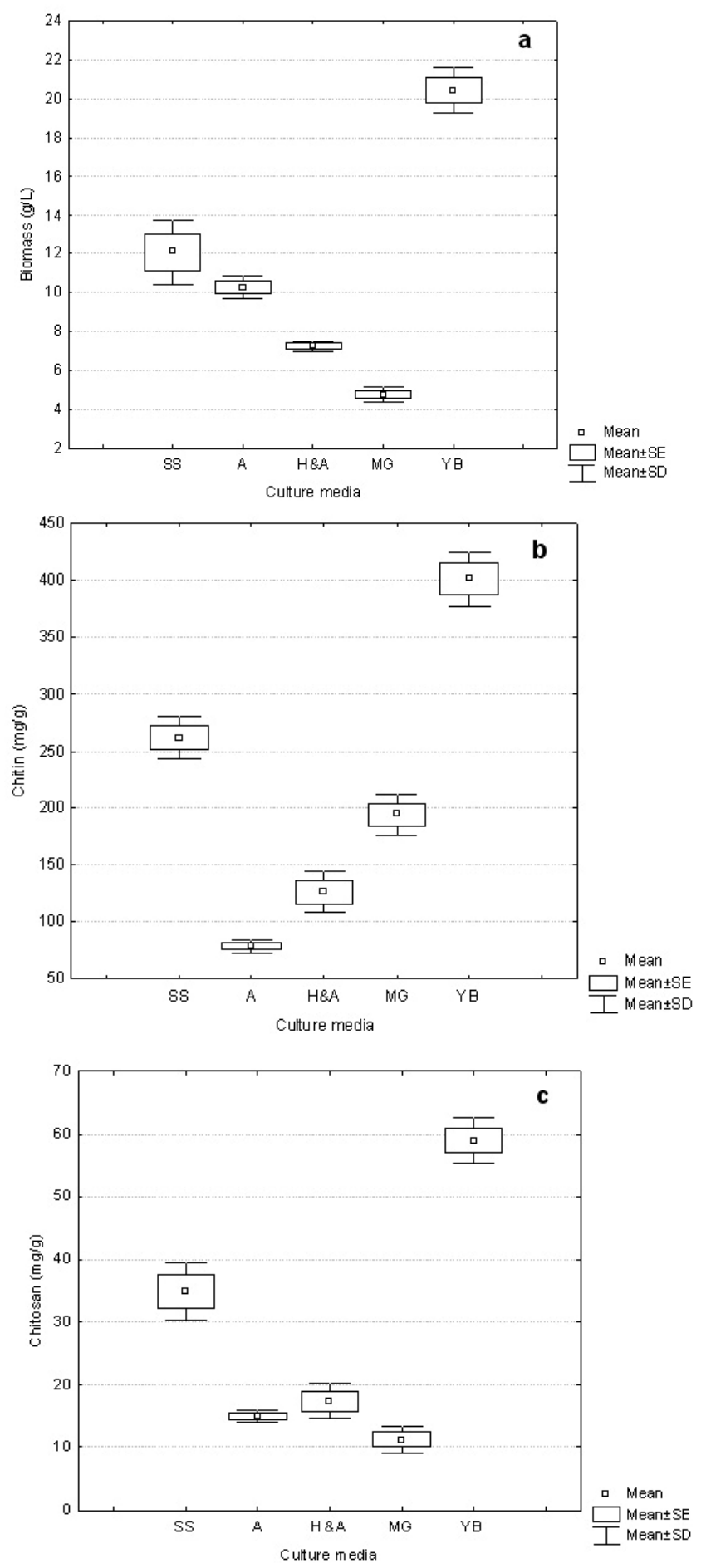

Figure 1. Cunninghamella elegans (UCP 542) grown in different culture media, after 96 hrs of time cultivation, at $28^{\circ} \mathrm{C}, 150 \mathrm{rpm}$.

(a) Biomass production.

(b) Yield of chitin.

(c) Chitosan extracted of dry weight biomass.

Legend: SS (Sabouraud Sucrose), A (Medium proposed by Andrade et al.), H\&A (Hesseltine and Anderson medium), MG (Malte glucose) and YB (Yam Bean medium) (glucose $(40 \mathrm{~g})$; asparagine $(2 \mathrm{~g})$; chloridrate of thiamine $(0.05 \mathrm{mg})$; potassium phosphate $(0.50 \mathrm{~g})$ and magnesium sulphate $(0.25 \mathrm{~g})$ per litre of distilled water, $\mathrm{pH} 5.2)$; $\mathrm{c})$ Andrade et al. (2000)- (glucose (60 g); asparagine (3 g); chloridrate of thiamine $(0.08 \mathrm{mg})$; potassium phosphate $(0.50 \mathrm{~g})$ and magnesium sulphate $(0.25 \mathrm{~g})$ per litre of distilled water, $\mathrm{pH} 5.1$ ); d) Malte glucose- (Yeast Malte (17

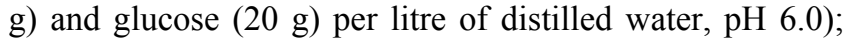
and e) Yam Bean Medium (Pachyrhizus erosus L. Urban)basic chemical composition (total protein $(8.72 \mathrm{~g})$, Starch $(40.9 \mathrm{~g})$ and glucose (11.14 g) per litre of distilled water, $\mathrm{pH}$ 7.0). Tuberous roots of yam bean were provided by the Department of Agronomy at Federal Rural University of Pernambuco (Northeast Brazil). The tuberous roots surface were washed with water and soap, for withdrawal of impurities. The Yam Bean Medium was prepared from tuberous roots peeled and rounded sliced $( \pm 1,5 \mathrm{~cm})$ and boiled in distilled water in the ratio of 1:2 (w/v) for $45 \mathrm{~min}$ (after initiate the boil). The broth was cooled, filtered in filter of paper and autoclavated at $121,5^{\circ} \mathrm{C}, 15 \mathrm{~min}$.

\section{Microbiological methods}

Growth profile. The sporangioles of $C$. elegans were harvested from cultures grown for seven days at $28^{\circ} \mathrm{C}$ on Petri dishes containing PDA medium. A suspension was prepared and adjusted to $10^{8}$ sporangioles $/ \mathrm{mL}$, using a hematocytometer for counting. For fungal submerse cultivation, $10 \mathrm{~mL}$ sporangioles suspension $\left(10^{8}\right.$ sporangioles $/ \mathrm{mL}$ ) were inoculated in Erlenmeyer flask of $1000 \mathrm{~mL}$ containing $290 \mathrm{~mL}$ of culture media, and the flasks were incubated at $28^{\circ} \mathrm{C}$ in an orbital shaker at 150 rpm, during 96 hrs. The mycelia were harvested, washed twice in distilled and deionised water by filtration, utilizing a silkscreen nylon membrane (120 F), and were submitted to lyophilization process. After lyophilization the biomass was maintained in a vacuum dissecator until constant weight. During $C$. elegans submerse cultivation in yam bean medium, aliquots were collected every $24 \mathrm{hrs}$ for biomass, $\mathrm{pH}$, glucose and total nitrogen determination.

\section{Analytical methods}

Glucose and nitrogen consumption and $\mathrm{pH}$ determination. The glucose consumption was determined by the enzymatic colorimetric method $\left(\right.$ Labtest $^{\circledR}$ Kit Glucose oxidase). A standard curve was made by using a range of glucose solutions $(0.5$ to $10.0 \mathrm{~g} / \mathrm{L})$. Colorimetric method Labtest ${ }^{\circledR}$ Kit for protein was utilized for the nitrogen consumption determination, using a spectrophotometer Spectronic Genesys 2. Changes in $\mathrm{pH}$ were measured using a potentiometer (Digital Pontentiometer Quimis Mod. 400 A). All assays were performed two times.

Chitin and chitosan extraction. The process of extraction involved deproteination with $2 \% \mathrm{w} / \mathrm{v}$ sodium hydroxide solution $\left(30: 1 \mathrm{v} / \mathrm{w}, 90^{\circ} \mathrm{C}, 2 \mathrm{hrs}\right)$, separation of alkaliinsoluble fraction (AIF) by centrifugation (4000 rpm, 15 


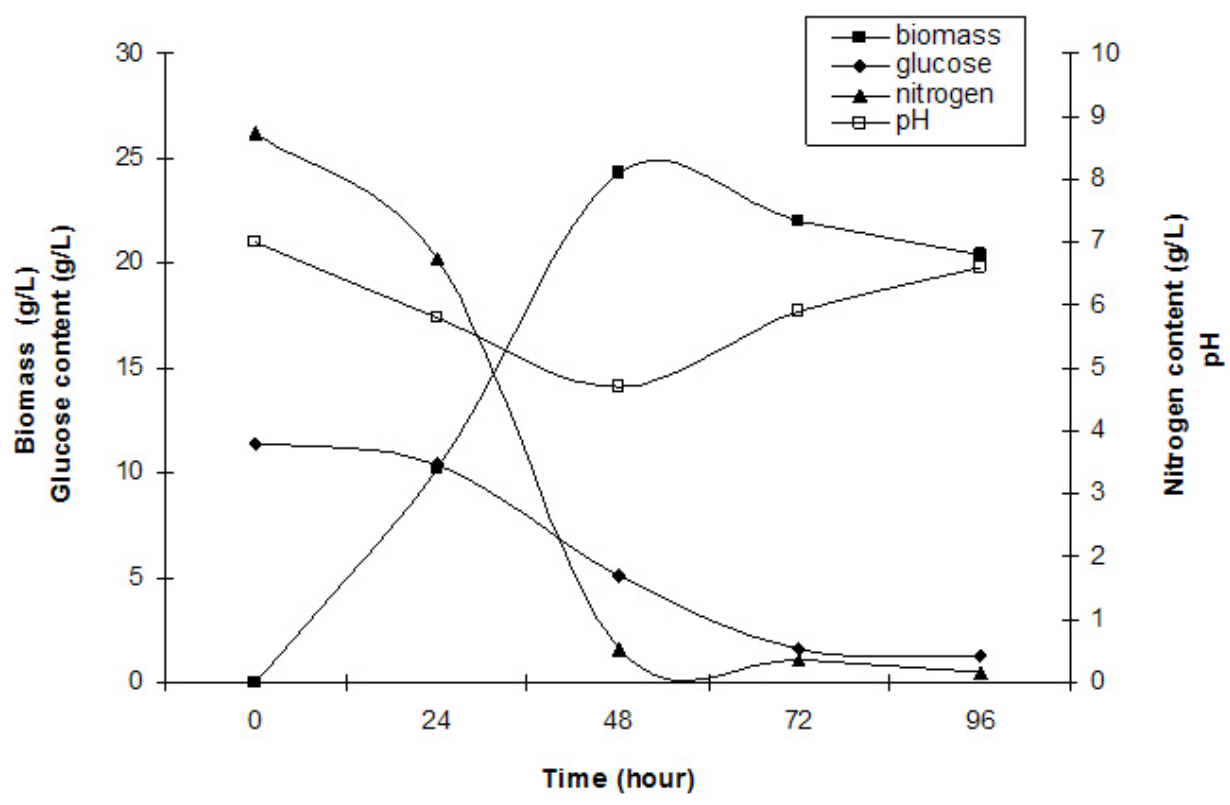

Figure 2. Curve of growth, glucose and nitrogen consumption of Cunninghamella elegans (UCP 542) grown in yam bean medium at $28^{\circ} \mathrm{C}, 150 \mathrm{rpm}$, during $96 \mathrm{hrs}$ of cultivation.

min), extraction of chitosan from AIF under reflux $(10 \%$ $\mathrm{v} / \mathrm{v}$ acetic acid $\left.40: 1 \mathrm{v} / \mathrm{w}, 60^{\circ} \mathrm{C}, 6 \mathrm{hrs}\right)$, separation of crude chitin by centrifugation (4000 $\mathrm{xg}, 15 \mathrm{~min})$ and precipitation of chitosan from the extract at $\mathrm{pH} 9.0$, adjusted with a $4 \mathrm{M}$ $\mathrm{NaOH}$ solution. Crude chitin and chitosan were washed on a coarse sintered-glass funnel with distilled water, ethanol and acetone and air-dried at $20^{\circ} \mathrm{C}$ (Franco et al. 2004).

\section{Chitin and chitosan characterization}

Infrared spectroscopy (Deacetylation degree - DD\%). The degree of deacetylation for microbial chitin and chitosan were determined using the infrared spectroscopy according to Roberts (1992), using the absorbance ratio A1655/A3450 and calculated according to equation 1:

$$
A(\%)=(A 1655 / A 3450) \times 100 / 1.33
$$

Two milligrams sample of fungal chitin and chitosan, which had been dried overnight at $60^{\circ} \mathrm{C}$ under reduced pressure were thoroughly blended with $100 \mathrm{mg}$ of $\mathrm{KBr}$, to produce $0.5 \mathrm{~mm}$ thick disks. The disks were dried for 24 hrs at $110^{\circ} \mathrm{C}$ under reduced pressure. Infrared spectrometer was recorded with a Bruker 66 Spectrometer, using a 100 $\mathrm{mg} \mathrm{KBr}$ disks for reference. The intensity of maximum absorption bands were determined by the baseline method.

Molecular weight. The molecular weights of chitin and chitosan were determined by viscosity, using the procedure described by Dos Santos et al. (2003). The viscosity of chitosan was determined using an AVS-350 viscometer (Schott-Geräte), type/capillary: Cannon-Fensked inside $=1.01$ $\mathrm{mm}$, at $25^{\circ} \mathrm{C}$. After getting the intrinsic viscosity from tables $\mathrm{K}$ and a, were obtained for $\mathrm{HAc} / \mathrm{NaAc}$. $\mathrm{K}=0.076$, a
$=0.76$. The flow time was determined in seconds. Using Mark-Houwinks equation the average viscosimetric molecular weight expressed in $\mathrm{g} / \mathrm{mol}$. See equation 2 .

$$
[\eta]=K\left(\bar{M}_{v}\right)^{a}
$$

\section{Statistic analysis}

The data were analyzed for significance using the Student's t-test and chi-square test using STATISTICA program version 6.0 of Statsolt Inc., USA. All experiments were carried out in triplicate and the results are expressed as mean \pm S.D.

\section{RESULTS AND DISCUSSION}

The profile of growth of C. elegans (UCP 542) and chitin /chitosan production using yam bean medium and four different culture media, traditional for Mucorales, are showed in Figure 1. A higher production of biomass, statistically significant $(p=0.0028)$ can be verified in the yam bean medium, with average dry weight corresponding to $20.4 \mathrm{~g} / \mathrm{L}$ (Figure 1a). In addition, the best yield of chitin and chitosan per $1 \mathrm{~g}$ of biomass from C. elegans (UCP 542) are obtained using yam bean medium and Sabouraud sucrose medium for chitin $400.9 \mathrm{mg} / \mathrm{g}$ and $261,7 \mathrm{mg} / \mathrm{g}$ and chitosan 58,9 mg/g and 34,9 mg/g, respectively (Figure $1 \mathrm{~b}$ and Figure 1c). The results are superior to the reported by Andrade et al. (2000) and Franco et al. (2005) which proposed C. elegans as a promising chitin source, obtained as higher chitin yields $280 \mathrm{mg} / \mathrm{g}$ and $240 \mathrm{mg} / \mathrm{g}$, 
respectively. Andrade et al. (2003) reported a maximum chitin yield of $239 \mathrm{mg} / \mathrm{g}$ from Mucor javanicus.

However, C. elegans (UCP 542) grown in Hesseltine and Anderson medium shows a biomass yield of $10.3 \mathrm{~g} / \mathrm{L}$, with $96 \mathrm{hrs}$ of cultivation. The result is in agreement with the growth curve of C. elegans (IFM 46109) established by Andrade et al. (2000) and Franco et al. (2005) using the same culture medium, which referred biomass yield of 11.0 and $11.6 \mathrm{~g} / \mathrm{L}$, respectively.

C. elegans (UCP 542) grown in malt medium with glucose $2 \%$ during $96 \mathrm{hrs}$, shows average biomass production of 4.8 $\mathrm{g} / \mathrm{L}$. This result is similar to the reported by Synowiecki and Al-Khatteb (1997) which obtained a yield biomass of Mucor rouxii grown in yeast extract and glucose $2 \%$ medium, for $48 \mathrm{hrs}$, to the $4 \mathrm{~g}$, per litre of medium.

Chitin and chitosan production by $C$. elegans grown in yam bean medium are studied on the cultivation profile. $C$. elegans (UCP 542) growth curve for biomass, $\mathrm{pH}$, nitrogen content and glucose consumption is present in Figure 2. Biomass production increase rapidly up to $48 \mathrm{hrs}$, reached about the maximum of $24.3 \mathrm{~g} / \mathrm{L}$ of dry weight. The result is superior to the value $10.41 \mathrm{~g} / \mathrm{L}$ and $11.6 \mathrm{~g} / \mathrm{L}$ reported by Andrade et al. (2000) and Franco et al. (2004), respectively, for C. elegans (URM 46109) grown during $96 \mathrm{hrs}$ in Mucorales medium.

The results in Figure 2, demonstrate the residual glucose and nitrogen were $1.27 \mathrm{~g} / \mathrm{L}$ and $0.18 \mathrm{~g} / \mathrm{L}$ respectively.
Similar results were reported by Andrade et al. (2000) and Franco et al. (2004). Amorim et al. (2001) suggested that the remaining glucose and nitrogen as due to nitrogenous compounds like secondary metabolites present at the end of growth of the fungi metabolism and excess of carbon source in the medium.

The $\mathrm{pH}$ of yam bean medium oscillates between 7 and 5 , during the culture time (Figure 2). The values of $\mathrm{pH}$ decrease during the exponential phase, probably, by pyruvic acid formation, as due to the high glucose and starch concentration in yam bean medium. Franco et al. (2004) described constant values of $\mathrm{pH}$ during the "lag" phase and $\mathrm{pH}$ decrease during the exponential phase. That information of higher amount of the yam bean glucose and starch was previously mentioned by Sarangbin and Watanapokasin (1999), during the citric acid production. Amorim et al. (2001) reported that during growth of $C$. elegans the $\mathrm{pH}$ of the media drops in the first $24 \mathrm{hrs}$ and remained low (between 3 and 4) during the first $96 \mathrm{hrs}$ of cultivation, probably because of the interaction between the medium substrate and the release of ions from the cell.

Figure 3 shows chitin and chitosan yield extracted, to each $24 \mathrm{hrs}$, from C. elegans (UCP 542) grown in yam beam medium during $96 \mathrm{hrs}$ of cultivation. The best yields of the polysaccharides (mg per gram of dry mycelia biomass) are obtained with $48 \mathrm{hrs}$ of culture for chitosan $(66 \mathrm{mg} / \mathrm{g}$ or $6.6 \%)$ and with $72 \mathrm{hrs}$ for chitin $(440 \mathrm{mg} / \mathrm{g}$ or $44 \%)$. Similar results were reported to Tan et al. (1996), which studied different Zygomycetes strains and observed that

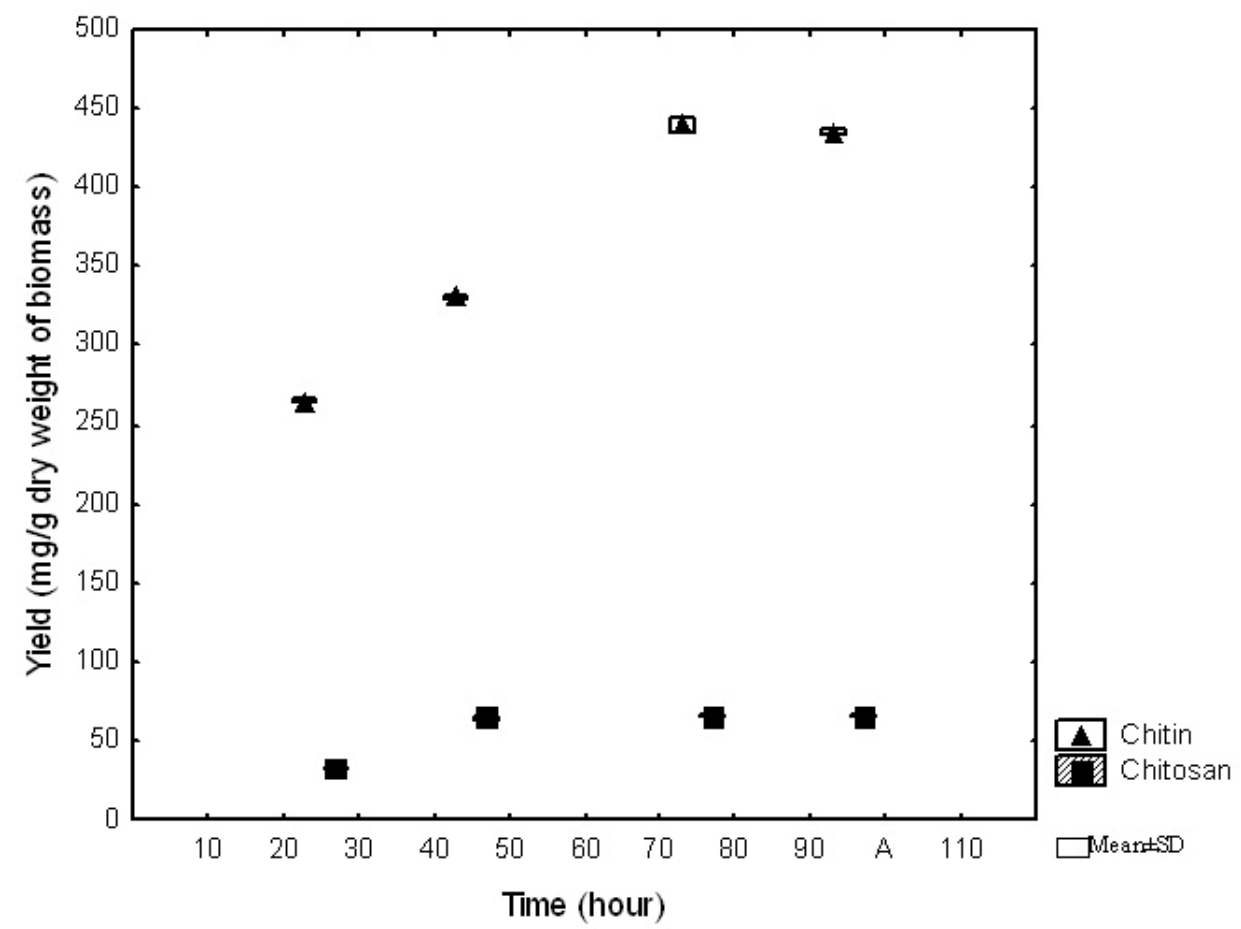

Figure 3. Chitin ( $\mathrm{mg} / \mathrm{g}$ ) and chitosan ( $\mathrm{mg} / \mathrm{g}$ ) production from biomass of Cunninghamella elegans (UCP 542) grown in yam bean medium, at $28^{\circ} \mathrm{C}, 150 \mathrm{rpm}$ during $96 \mathrm{hrs}$ of cultivation. 
Cunninghamella echinulata was the best chitosan producing strain, with a yield of approximately $7.0 \%$ of chitosan per mycelia dry weight.

Chitosan production stabilize after $48 \mathrm{hrs}$ of culture, although, chitin production increase up to $72 \mathrm{hrs}$ of culture, and decrease at $96 \mathrm{hrs}$. The higher chitosan yields in $48 \mathrm{hrs}$ of growth suggest that during initial growth chitin is less crystalline and thus more susceptible to chitin deacetylase, and the chitosan formed by this enzime prevails in acid $\mathrm{pH}$ (Figure 3). According to Amorim et al. (2005) optimum pH for chitin deacetylase activity from Zygomycetes is $\mathrm{pH} 4.5$. During C. elegans growth the $\mathrm{pH}$ of the yam bean medium drops in the first 48 hrs (Figure 2), stowing high metabolic interchange between the medium substrate uptake and the release of ions from the cells. Amorim et al. (2001) reported higher yields of chitosan were found within $24 \mathrm{hrs}$ of cultivation of M. racemosus and C. elegans at $\mathrm{pH} 3.5$, which seems to be also a stimulating agent for production of this biopolymer. The data in the present work are in agreement with Pochanavanich and Suntornsuk (2002) and Nadarajah et al. (2001) that chitosan production by the microorganisms is strongly dependent of the culture conditions, including cultivation time. Chung et al. (2004) demonstrated that chitin and chitosan content in the cellular wall of fungi change according to the species and these polymers usually show higher values in Zygomycetes.

The characterization of chitin and chitosan obtained from C. elegans in yam bean medium by infrared spectra are similar to those reported in the literature (Andrade et al. 2000; Amorim et al. 2001; Franco et al. 2005). The most significant parts of chitin and chitosan spectra are those showing the amide bands at approximately $1665,1555 \mathrm{e}$ $1313 \mathrm{~cm}^{-1}$, which could be assigned to the $\mathrm{C}=\mathrm{O}$ stretching, the $\mathrm{N}-\mathrm{H}$ deformation in the $\mathrm{CONH}$ plane and the $\mathrm{CN}$ bond stretching plus $\mathrm{CH}_{2}$ wagging. In a similar way, chitin from C. elegans shows bands in the amide II region, which were 1153,1378 and $1558 \mathrm{~cm}^{-1}$. The results are in agreement with Shigemasa and Minami (1996). Andrade et al. (2003) and Franco et al. (2005) which reported that chitin structure containing two types of amide group and both form $\mathrm{C}=\mathrm{O}$ $\mathrm{N}-\mathrm{H}$ intermolecular bonds, but one is also an acceptor for the $\mathrm{CH}_{2} \mathrm{OH}$ group.

According to Dos Santos et al. (2003) the deacetylation and the regeneration process, cause disturbance in the initial crystalline reticulum of chitin, inducing a reordering of the hydrogen linking of chitosan. This can be observed in the central band at approximately $3483 \mathrm{~cm}^{-1}$ e $3305 \mathrm{~cm}^{-1}$, in the region of the axial deformation of $\mathrm{OH}$, which appears overlapping the band of axial deformation of $\mathrm{NH}$ indicating the intermolecular hydrogen linking formation, and at the displacement of the higher frequency band indicating an increase in the structural order. The data are in accordance with the reported in literature when comparing both chitin and chitosan infrared spectra obtained by microbiological methods (Andrade et al. 2000; Amorim et al. 2001;
Pochanavanich and Suntornsuk, 2002; Dos Santos et al. 2003; Franco et al. 2005).

Deacetylation degree (\%DD) is an important parameter associated with the physical-chemical properties of chitosan, because it's linked directly to the chitosan cationic properties (Pochanavanich and Suntornsuk, 2002). In the present study chitin and chitosan from $C$. elegans grown in yam bean medium present $6,2 \% \mathrm{DD}$ and $85 \%$ DD, respectively. Amorim et al. (2001), Pochanavanich and Suntornsuk (2002) and Franco et al. (2004), reported deacetylation degree of chitosan from fungi between 80 to $90 \%$ DD.

The average viscosimetric molecular weight $\left(M_{V}\right)$ of chitin and chitosan from $C$. elegans obtain in the present research are $3.25 \times 10^{4} \mathrm{~g} / \mathrm{mol}$ for chitin, and $2.72 \times 10^{4} \mathrm{~g} / \mathrm{mol}$ for chitosan. The results are in agreement with the results found in the literature, molar weights ranged between $1,0 \mathrm{x}$ $10^{4}$ to $9,0 \times 10^{5} \mathrm{~g} / \mathrm{mol}$ (Nadarajah et al. 2001; Pochanavanich and Suntornsuk, 2002; Dos Santos et al. 2003).

The results present here suggest a high biotechnological potential of yam bean as an economic medium to chitin and chitosan production by $C$. elegans, and may be used to reduce the cost price of these polysaccharides production.

\section{REFERENCES}

AMORIM, Rosa Valéria da Silva; DE SOUZA, Wanderley; FUKUSHIMA, Kazutaka and CAMPOS-TAKAKI, Galba Maria. Faster chitosan production by Mucoralean strains in submerged culture. Brazilian Journal of Microbiology, January-March 2001, vol. 32, no. 1, p. 20-23.

AMORIM, R.V.S.; LEDINGHAM, W.M.; FUKUSHIMA, K. and CAMPOS-TAKAKI, G.M. Screening of chitin deacetylase from Mucoralean strains (Zygomycetes) and its relationship to cell growth rate. Journal of Industrial Microbiology and Biotechnology, January 2005, vol. 32, no. 1, p. 19-23.

ANDRADE, V.S.; NETO, B.B.; SOUZA, W. and CAMPOS-TAKAKI, G.M. A factorial designs analysis of chitin production by Cunninghamella elegans. Canadian Journal of Microbiology, November 2000, vol. 46, no. 11, p. 1042-1045.

ANDRADE, Vânia Sousa; BARROS NETO, Benício de; FUKUSHIMA, Kazutaka and CAMPOS-TAKAKI, Galba Maria. Effect of medium components and time of cultivation on chitin production by Mucor circinelloides (Mucor javanicus IFO 4570) - A factorial study. Revista Iberoamericana de Micología, 2003, vol. 20, p. 149-153.

CAMPOS-TAKAKI, Galba Maria. The fungal versatility on the copolymers chitin and chitosan production. In: DUTTA, P.K. ed. Chitin and chitosan opportunities and 
challenges, India, SSM: International Publication, 2005, p. 69-94.

CHUNG, Ying-Chien; SU, Ya-Ping; CHEN, ChiingChang; JIA, Guang; WANG, Huey-Lan; WU, J.C. Gaston and LIN, Jaung-Geng. Relationship between antibacterial activity of chitosan and surface characteristics of cell wall. Acta Pharmacologica Sinica, July 2004, vol. 25, no. 7, p. 932-936.

DOS SANTOS, José E.; SOARES, João da P.; DOCKAL, Edward R.; FILHO, Sergio P. Campana and CAVALHEIRO, Eder T.G. Caracterização de quitosanas comerciais de diferentes origens. Polímero: Ciência e Tecnologia, October-December 2003, vol. 13, no. 4, p. 242249.

FRANCO, Luciana de Oliveira; MAIA, Rita de Cássia Gomes; PORTO, Ana Lúcia F.; MESSIAS, Arminda Sacconi; FUKUSHIMA, Kazutaka and CAMPOSTAKAKI, Galba Maria. Heavy metal biosorption by chitin and chitosan isolated from Cunninghamella elegans (IFM 46109). Brazilian Journal of Microbiology, July-September 2004, vol. 35, no. 3, p. 243-247.

FRANCO, Luciana de Oliveira; STAMFORD, Thayza Christina Montenegro; STAMFORD, Newton Pereira and CAMPOS-TAKAKI, Galba Maria de. Cunningamella elegans (IFM 46109) como fonte de quitina e quitosana. Revista Analytica, December-January 2005, vol. 4, no. 14, p. $40-44$.

KATO, Y.; ONISHI, H. and MACHIDA, Y. Application of chitin and chitosan derivatives in the pharmaceutical field. Current Pharmaceutical Biotechnology, October 2003, vol. 4, no. 5, p. 303-309.

MURUGAN, R. and RAMAKRISHNA, S. Bioresorbable composite bone paste using polysaccharide based nanohydroxyapatite. Biomaterials, August 2004, vol. 25, no. 17 , p. 3829-3835.

NADARAJAH, K.; KADER, J.; MAZMIRA, Mohd and PAUL, D.C. Production of chitosan by fungi. Pakistan Journal of Biological Sciences, 2001, vol. 4, no. 3, p. 263265.

NEMTSEV, S.V.; ZUEVA, O. Yu; KHISMATULLIN, M.R.; ALBULOV, A.I. and VARLAMOV, V.P. Isolation of chitin and chitosan from honeybees. Applied Biochemistry and Microbiology, January 2004, vol. 40, no. 1, p. 39-43.

POCHANAVANICH, P. and SUNTORNSUK, W. Fungal chitosan production and its characterization. Letters in Applied Microbiology, July 2002, vol. 35, no. 1, p. 17-21.

ROBERTS, George A.F. Chitin Chemistry. London, MacMillan Press, 1992. 350 p. ISBN 0-33-352417-9.
SARANGBIN, Somsak and WATANAPOKASIN, Yuwadee. Yam bean starch: a novel substrate for citric acid production by the protease-negative mutant strain of Aspergillus niger. Carbohydrate Polymers, March 1999, vol. 38 , no. 3, p. 219-224.

SHIGEMASA, Y. and MINAMI, S. Applications of chitin and chitosan for biomaterials. Biotechnology and Genetic Engineering Reviews, 1996, vol. 17, p. 413-420.

SORENSEN, M. Yam bean: Pachyrhizus D.C. Rome, International Plant Genetic Resources Institute, 1996. 140 p. ISBN 92-9043-282-9.

STAMFORD, Tania Lúcia Montenegro; ARAÚJO, Janete Magali and STAMFORD, Newton Pereira. Atividade enzimática de microrganismos isolados do jacatupé (Pachyrhizus erosus L. Urban). Ciência e Tecnologia dos Alimentos, October-December 1998, vol. 18, no. 4, p. 382385.

STAMFORD, T.L.M.; STAMFORD, N.P.; COELHO, L.C.B.B. and ARAÚJO, J.M. Production and characterization of a thermostable $\alpha$-amylase from Nocardiopsis sp. endophyte of yam bean. Bioresource Technology, January 2001, vol. 76, no. 2, p. 137-141.

STAMFORD, N.P.; FREITAS, A.D.S.; FERRAZ, D.S.; MONTENEGRO, A. and SANTOS, C.E.R.S. Nitrogen fixation and growth of cowpea (Vignaunguiculata) and yam bean (Pachyrhizus erosus) in a sodic soil as affected by gypsum and sulphur inoculated with Thiobacillus and rhizobial inoculation. Tropical Grasslands, March 2003, vol. 37, no. 1, p. 11-19.

SYNOWIECKI, Józef and AL-KHATTEB, Nadia Ali Abdul. Mycelia of Mucorrouxii as a source of chitin and chitosan. Food Chemistry, December 1997, vol. 60, no. 4, p. 605-610.

SYNOWIECKI, Józef and AL-KHATTEB, Nadia Ali Abdul. Production, properties, and some new applications of chitin and its derivatives. Critical Reviews in Food Science and Nutrition, March 2003, vol. 43, no. 2, p. 145171.

TAKEUCHI, Hirofumi; YAMAMOTO, Hiromitsu and KAWASHIMA, Yoshiaki. Mucoadhesive nanoparticulate systems for peptide drug delivery. Advanced Drug Delivery Reviews, March 2001, vol. 47, no. 1, p. 39-54.

TAN, Su Ching; TAN, Teck Koon; WONG, Sek Man and KHOR, Eugene. The chitosan yield of zygomycetes at their optimum harvesting time. Carbohydrate Polymers, August 1996, vol. 30, no. 4, p. 239-242.

THARANATHAN, Rudrapatnam N. and KITTUR, Farooqahmed S. Chitin-the undisputed biomolecule of great potential. Critical Reviews in Food Science and Nutrition, January 2003, vol. 43, no. 1, p. 61-87. 
Stamford, T.C. et al.

YADAV, A.V. and BHISE, S.B. Chitosan: a potential biomaterial effective against typhoid. Current Science, November 2004, vol. 87, no. 9, p. 1176-1178.

YUSOF, Nealda Leila Binte Muhammad; WEE, Aileen; LIM, Lee Yong and KHOR, Eugene. The flexible chitin films as potential wound-dressing materials: Wound model studies. Journal of Biomedical Materials Research Part A, August 2003, vol. 66A, no. 2, p. 224-232. 